medRxiv preprint doi: https://doi.org/10.1101/2020.08.29.20184366; this version posted September 13, 2020. The copyright holder for this preprint (which was not certified by peer review) is the author/funder, who has granted medRxiv a license to display the preprint in perpetuity.

All rights reserved. No reuse allowed without permission.

\title{
Potential Community and Campus Covid-19 Outcomes Under University and College Reo- pening Scenarios
}

James C. Benneyan, Christopher Gehrke, Iulian Ilieş, Nicol Nehls

Healthcare Systems Engineering Institute, Northeastern University, Boston, MA, USA

Corresponding author: James Benneyan, PhD, Healthcare Systems Engineering Institute, Northeastern University, 177 Huntington Avenue, Boston, MA 02115, j.benneyan@ northeastern.edu

\begin{abstract}
Background. Significant uncertainty exists in many countries about the safety of, and best strategies for, reopening college and university campuses until the Covid-19 pandemic is better controlled. Little also is known about the effects on-campus students may have on local higher-risk communities. We aimed to estimate potential community and campus Covid-19 exposures, infections, and mortality due to various university reopening and precaution plans under current ranges of assumptions and uncertainties.
\end{abstract}

Methods. We developed and calibrated campus-only, community-only, and campus-X-community epidemic differential equation and agent-based models. Input parameters for campus and surrounding communities were estimated via published and grey literature, scenario development, expert opinion, accuracy optimization algorithms, and Monte Carlo simulation; models were cross-validated against each other using February-June 2020 data from heterogeneous U.S. counties and states. Campus opening plans (spanning various fully open, hybrid, and fully virtual approaches) were identified from websites and publications. All scenarios were simulated assuming 16-week semesters and estimated ranges for Covid-19 prevalence among community residents and arriving students, precaution compliance, contact frequency, virus attack rates, and tracing and isolation effectiveness. Additional student and community exposures, infections, and mortality were estimated under each scenario, with $10 \%$ trimmed medians, standard deviations, and probability intervals computed to omit extreme outlier scenarios. Factorial analyses were conducted to identify intervention inputs with largest and smallest effects.

Results. As a base case with no precautions (or no compliance), predicted 16-week student infections and mortality under normal operations ranged significantly from 471 to 9,495 (median: 2,286, SD: 2,627) and 0 to 123 (median: 9, SD: 14) per 10,000 students, respectively. The maximum active exposures across a semester was $15.76 \%$ of all students warranting tracing. Total additional community exposures, infections, and mortality ranged from 1 to 187,13 to 820 , and 1 to 21 per 10,000 residents, respectively. $1 \%$ and $5 \%$ of on-campus students were infected after a mean (SD) of 11 (3) and 76 (17) days, respectively; >10\% students infected by the end of a semester in $34.8 \%$ of scenarios, with the greatest increase (first inflection point) occurring on average on day 84 (SD: 10.2 days). Common reopening precautions reduced infections by $24 \%$ to $26 \%$ and mortality by $36 \%$ to $50 \%$ in both populations. Uncertainties in many factors, however, produced tremendous variability in all results, ranging from medians by $-67 \%$ to $+342 \%$. 
Conclusions. Consequences on community and student Covid-19 exposures, infections, and mortality of reopening physical campuses are very highly unpredictable, depending on a combination of random chance, controllable (e.g. physical layouts), and uncontrollable (e.g. human behavior) factors. Implications include needs for criteria to adapt campus operations mid-semester, methods to detect when necessary, and contingency plans for doing so.

\section{Introduction}

The Covid-19 disease pandemic has had devastating human, financial, and logistical impacts worldwide, including an estimated 19 million infected and 722,000 deaths ${ }^{1}$ (as of July 2020), radical changes to work and life routines, economic recession, and increased social inequities. ${ }^{2-5}$ Among many other issues, significant uncertainties exist about the safety, benefits, and potential consequences of reopening schools, ${ }^{6-9}$ heightened by resurgences in infections and mortality and campus-X-community cross-exposure concerns. ${ }^{9,10}$ While much initial focus was on K-12 education, ${ }^{11-13}$ similar college and university reopening concerns likely will continue for the next several academic terms. ${ }^{9,10,14}$

As the Covid-19 pandemic spread uncontrollably during the spring of 2020, nearly all K-12 and secondary schools suspended physical classes, with an estimated 50 million elementary ${ }^{13}$ and 19 million college U.S. students ${ }^{15}$ shifting to online learning, home schooling, and remote education, with experiences varied and often lacking. ${ }^{16-18}$ While early in summer 2020 a few universities decided to remain fully virtual for the following academic year, ${ }^{19}$ including the largest public university system in the United States, ${ }^{19,20}$ many schools communicated their intent to reopen and started planning accordingly. Four events have since occurred of parallel import: several additional colleges and universities switched to full or partial on-line plans for the fall 2020 semester, Covid-19 has resurged in many regions, others have moved forward nonetheless to open as safely as possible, and debate has increased as to what best balances education, safety, and economic needs. ${ }^{21-26}$

Examples of reopening plans range from full on-campus operations with contact precautions, hybrid virtual/physical formats with some courses (or class meetings within given courses) taught virtually and others in-person, having only first and/or second year students on campus with all others virtual, student choice to take any courses physically versus virtually, and (in the U.S.) accelerated semesters to end at Thanksgiving holiday to reduce travel-based spread. ${ }^{27-29}$ Efforts to limit on-campus exposures include reconfigured classrooms and dormitory spaces, precaution awareness campaigns, hotel room rentals to reduce living density, testing and tracing plans of varied rigor, returning student isolation, dedicated living spaces tested-positive students, and other strategies that attempt to reduce density and exposure rates. ${ }^{21,23,27,30-32}$

Significant uncertainty, however, exists about the effectiveness of any of these plans. ${ }^{21,33,23,31}$ The best current diagnostic tests have variable and poor clinical sensitivity, ${ }^{25,34}$ an estimated 30 $40 \%$ of positive individuals never exhibit symptoms, ${ }^{25,34,35}$ incubation delays from exposure to symptomatic average 3-5 days, ${ }^{35-37}$ and on-campus compliance to distancing precautions. 25,30,38,39 Contact tracing, while helpful, may not work as well for Covid-19 given the above 9,33 
and may be further limited here as students interact with many-fold more individuals (many unknowingly or unknown by name).

These uncertainties have prompted some to question university reopening safety, $6,8,14,26,31,4025$ especially in urban university settings with significant geographically dispersed student populations. ${ }^{41}$ Others have suggested Covid-19 might catalyze reinvention of higher education, ${ }^{42-45}$ including criticisms of prioritizing economics, brand, and survival over safety. ${ }^{22,43,44,46}$ The president of Paul Quinn College, for example, recently stated "Rushing to reopen our society and our schools is a mistake that will ultimately result in hundreds of thousands of citizens falling sick and worse. We should not let our own financial and reputational worries cloud our judgment about matters of life and death." 8 As elsewhere, not reopening may have large economic and student development effects, ${ }^{47-49}$ although perhaps less so the latter than K-12 schools. Not reopening could be untenable for colleges and universities already facing financial strains before Covid19 emerged. ${ }^{48-50}$

Although little empirical data exist yet on college reopening, ${ }^{40,51-56}$ experiences of pre-school, summer camp, and K-12 programs have been varied, ${ }^{57,58}$ with some outbreaks traced back to only a few index cases. ${ }^{21}$ Social gatherings of college-age students during summer 2020 also have resulted in outbreaks, ${ }^{38,58,59}$ including events and activities individuals advised against but participated in nonetheless. ${ }^{30,38}$ Despite early uncertainty, increasing evidence suggests studentaged individuals can carry and transmit the SARS-CoV-2 virus $35,58,60,61$ and significant betweenstudent spread occurs at college and high school levels ${ }^{35,58,61}$ (in contrast to younger K-5 students). ${ }^{35,47,61,62}$ The impacts of campus opening on spread to the surrounding community, with higher percentages of at-risk individuals, has been less reported on.

Given these combined uncertainties, we developed and applied single and multiple population Covid-19 spread models to investigate the range of potential community and campus impacts across a range of potential reopening scenarios. The intent is to provide model-based analysis to better inform, among other inputs, decision-making at a critical time in the Covid-19 pandemic. While similar model analyses have extensively studied other infectious disease policies, ${ }^{63-66}$ little investigation has focused on university reopening.

\section{Methods}

\section{Model Development and Validation}

We developed and validated single and multiple population differential equation (ODE) and agent-based models of Covid-19 spread within and between defined groups of individuals. The general model logic (Figure 1) was adapted from classic susceptible-exposed-infected-recovered (SEIR) frameworks ${ }^{67,68}$ similar to those reported on elsewhere for many other infectious disease concerns. ${ }^{63-76}$ The single population model describes spread dynamics within one defined population (e.g. on-campus students or local community residents) depending on input values, whereas the multi-population model additionally includes cross-exposure between two or more groups. All models were adapted from validated MatLab code used to study other epidemics over several years. 


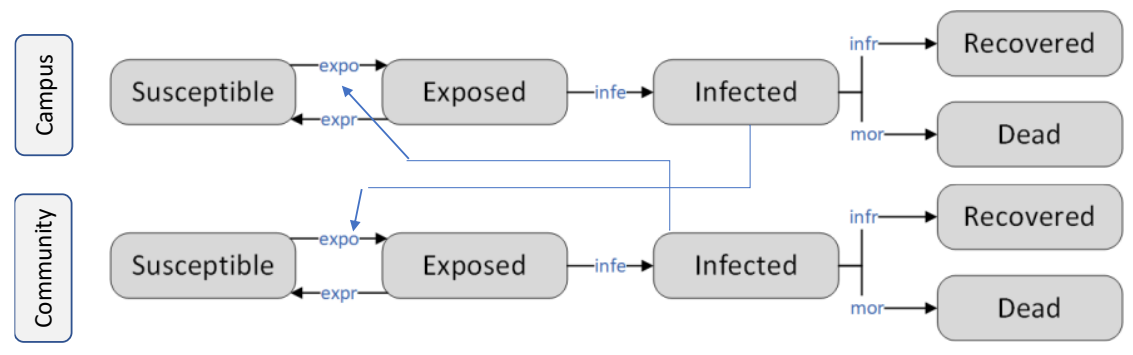

Figure 1. General logic of campus-x-community two-population Covid-19 disease spread model. (Suspectible: Individuals not currently infected but who can become infected; Exposed: Individuals who are exposed and potentially infected but not infectious yet to others; Infected: Individuals who are infected and can infect others; Recovered: Individuals who were infected, survived, and cannot become reinfected nor infect others within the study timeframe; Dead: Individuals who were infected and died from Covid-19 or complications).

State variables at time $t$ include the numbers of individuals in population $j$ that are Covid-free and susceptible $\left(S_{j}(t)\right)$, exposed to Covid but not yet infectious themselves $\left(E_{j}(t)\right)$, Covid-positive and infectious to others $\left(I_{j}(t)\right)$, recovered and not susceptible to re-infection $\left(R_{j}(t)\right)$, and Covidassociated deceased $\left(D_{j}(t)\right)$. Recovered individuals are assumed not to be able to re-infect, at least not with any appreciable rate within a one semester timeframe. ${ }^{37,77}$ Multiple dynamics change points were included for all parameters to allow for policy or behavior changes when fitting models to historical data. Each state variable is updated numerically at each time increment based on its previous value, current values of other state variables, and equations governing their interdependent relationships, with this process continuing iteratively for 16 weeks.

For example, the number of individuals in the susceptible population $\left(S_{j}(t)\right)$ is decremented by the number of newly exposed individuals $\left(S_{j}(t) \cdot\right.$ expo $\left._{j}\right)$ and increased by the number who previously were exposed but did not develop infections $\left(E_{j}(t) \cdot \operatorname{expr}_{j}\right)$, where the daily exposure rate

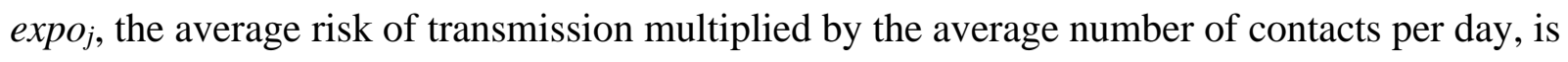
back-computed from the basic reproduction number $R_{0}$ (average number of new infections per infected individual) and recovery and mortality rates, and the recovery rate of non-infectious exposed individuals expr $r_{j}$ is calculated as the inverse of the corresponding recovery time $t_{r e c, n o n j}$.

In turn, the number of exposed individuals is increased by $S_{j}(t) \cdot$ expo $_{j}$ and decremented by the number who develop infections $\left(E_{j}(t) \cdot\right.$ infe $\left._{j}\right)$, where the daily infection rate expo $_{j}$ is the ratio of the probability of becoming infected upon exposure $p_{j}$ over the average incubation time $t_{i n c j}$. Infected individuals either recover or die at rates of $i n f r_{j} \cdot I_{j}(t)$ and $\operatorname{mort}_{j} \cdot I_{j}(t)$, respectively, where the daily recovery and mortality rates are the inverse of the average recovery time $t_{r e c, \text { inc } j}$ and the ratio of the overall COVID case fatality rate for that population $\left(C F R_{j}\right)$ over the average time from infection until death $t_{i 2 d_{j}}$, respectively. The change in each state variable and their governing rate change dynamics at each time step during numeric evaluation thus are:

\begin{tabular}{c|c}
$\underset{S}{\text { Susceptible }}$ & $\frac{d S_{j}(t)}{d t}=-\left(\operatorname{expo}_{j} \cdot \frac{I_{j}(t)}{N_{j}(t)}+r i_{j} \sum_{i \neq j} \chi_{i, j} \cdot \operatorname{expo}_{i} \cdot \frac{I_{i}(t)}{N_{i}(t)}\right)$ \\
$\cdot S_{j}(t)$ & $\cdot S_{j}(t)+\operatorname{expr}_{j} \cdot E_{j}(t)$
\end{tabular}
+ Not-infected/infectious (nor immune) after exposure - New exposures due to within-population and between-population contact with infectious individuals 


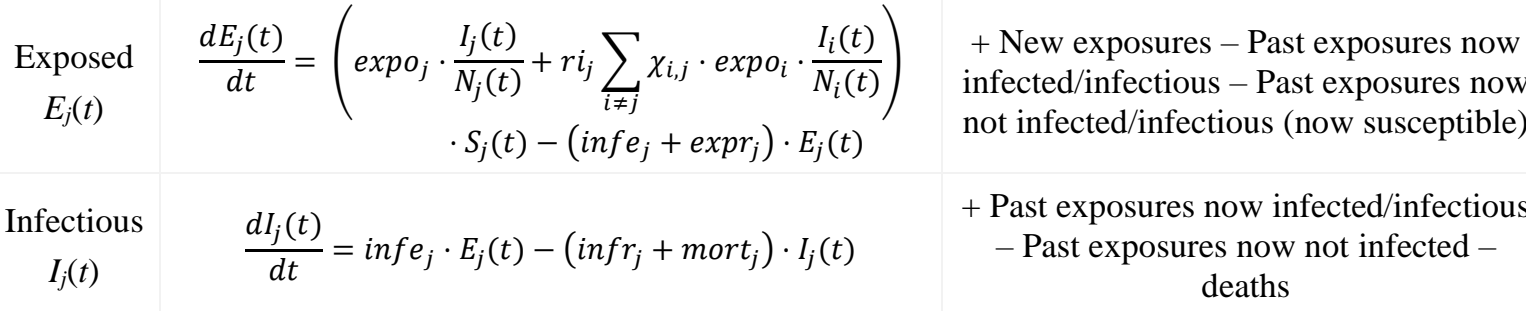

$$
\begin{aligned}
& \frac{d R_{j}(t)}{d t}=i n f r_{j} \cdot I_{j}(t) \\
& \text { + Infected individuals who recover } \\
& \text { (with immunity) } \\
& \text { + Covid-19 related deaths }
\end{aligned}
$$

where

$$
\begin{aligned}
& \operatorname{expo}_{j}=R_{0, j} \cdot \frac{i n f r_{j}+\text { mort }_{j}}{p_{j}} \\
& \text { inf } e_{j}=\frac{p_{j}}{t_{\text {inc } j}} \\
& \text { inf } r_{j}=\frac{1}{t_{r e c, i n f_{j}}} \\
& \operatorname{expr}_{j}=\frac{1-p_{j}}{t_{r e c, \text { non }_{j}}} \\
& \operatorname{mort}_{j}=\frac{C F R_{j}}{t_{i 2 d_{j}}} \\
& N_{i}=S_{i}(t)+E_{i}(t)+I_{i}(t)+R_{i}(t)+D_{i}(t)
\end{aligned}
$$

where $\chi_{i, j}=1$ if populations $i$ and $j$ are connected and 0 otherwise and $p_{j}=$ the proportion of exposed individuals that transition to infected (versus recovering to susceptible). The multi-population models allow for separate parameter values for each population, such as based on their demographics, with a cross-exposure parameter $\left(r i_{j}\right)$ defining the relative rate at which infectious individuals in one population expose susceptible individuals in the other (typically lower than within-population, assuming less interaction).

\section{Parameter Estimation and Calibration}

Model accuracy was validated using standard methods, ${ }^{65,78-82}$ cross-validation, and varied state and county empirical data (Jan-July 2020) exhibiting different epidemic patterns, magnitudes, and timings (Figure 2). In all cases model results closely emulate historical data, with accuracy on par with or exceeding norms and results reported elsewhere ${ }^{83-89}$ and with $\leq 1$ change points generally providing good fits, suggesting good prospective short-term prediction capability. 


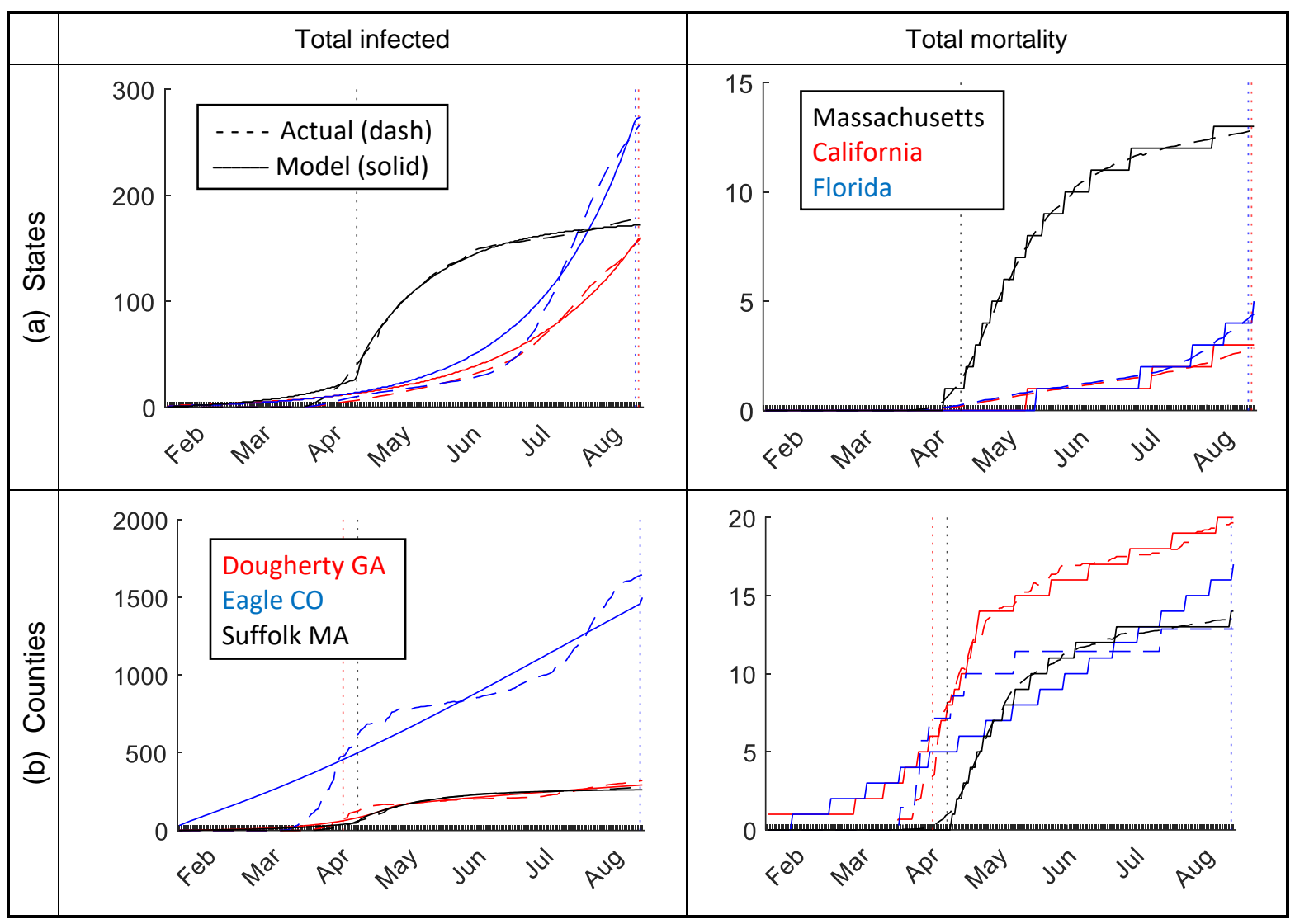

Figure 2. Examples of model accuracy; (a) U.S. state (shown: Massachusetts, California, and Florida) and (b) county (shown: Dougherty county GA, Eagle county CO, Suffolk county MA).

Table 1 summarizes input estimates used in the community and campus models, estimated as described above. For inputs with uncertainty, we used Monte Carlo simulations to create 1,000 synthetic results across plausible ranges, using the shown most likely, maximum, and minimum values to generate asymmetrical triangular distribution random variates. Since little data yet exist about on-campus spread, ${ }^{21}$ for exposure rates we used the shown ranges for the average number an infected student infects divided by the exposed-to-infectious percentage.

For community populations, we further calibrated inputs via meta-heuristic search algorithms (particle swarm, genetic algorithms, simulated annealing) to minimize root mean square error differences between historical and model-predicted infections and mortality, running each parameterization 1,000 times to produce 1,000 optimized input sets. For model fits with change points, separate values for all inputs were optimized for each time segment, with state variables at the start of each new time segment set to their values at the end of the prior segment.

For initial disease prevalence in the local community and among arriving students, we also used expected values and probability intervals from a validated epidemic data curve fitting algorithm. In the latter case, we predicted Covid-19 community prevalence at the start of the semester among arriving students using a proportionally weighted average of prevalence predictions based on home locations. Resulting community and student prevalence ranges were validated against data reported in recent media. Positive individuals at semester start-up were assumed distributed 
between exposed but not yet infectious (24.3\%) and infectious (75.7\%) groups based on approximate relative durations an average infected individual might spend in each state. For all analyses, $10 \%$ trimmed medians, standard deviations, and percentile intervals were computed to reduce any extreme outlier scenario effects.

\begin{tabular}{|c|l|c|c|c|c|c|c|}
\hline Parameter & \multicolumn{1}{|c|}{ Definition } & $\begin{array}{c}\text { Lower } \\
\text { Bound }\end{array}$ & $\begin{array}{c}\text { Most } \\
\text { Likely }\end{array}$ & $\begin{array}{c}\text { Upper } \\
\text { Bound }\end{array}$ & Sources & \multicolumn{2}{|c|}{ Rank } \\
\cline { 5 - 8 } & \multicolumn{1}{|c|}{ Infection } & Mortality \\
\hline$R_{0,1}$ & $\begin{array}{l}\text { Average number of students who be- } \\
\text { come infected by infectious students }\end{array}$ & 0.66 & 1 & 3.4 & {$[90]$} & $2(6)$ & $5(-)$ \\
\hline$R_{0,2}$ & $\begin{array}{l}\text { Average number of residents who be- } \\
\text { come infected by infectious residents }\end{array}$ & 0.66 & - & 3.4 & $\begin{array}{c}{[90], \text { param- }} \\
\text { eter search }\end{array}$ & $5(2)$ & $-(5)$ \\
\hline$r i_{j}$ & $\begin{array}{l}\text { Cross-exposure parameter (campus } x \\
\text { community) }\end{array}$ & 0.005 & 0.008 & 0.02 & estimated & $6(6)$ & $-(-)$ \\
\hline$\pi_{1}$ & $\begin{array}{l}\text { Proportion of student population that is } \\
\text { initially infected at semester start }\end{array}$ & 0.001 & .01 & .05 & {$[91-93]$} & $4(-)$ & $6(-)$ \\
\hline$\pi_{2}$ & $\begin{array}{l}\text { Proportion of community population } \\
\text { that is initially infected at semester start }\end{array}$ & 0.0016 & .01 & .016 & {$[94]$} & $-(4)$ & $(7)$ \\
\hline$p_{j}$ & $\begin{array}{l}\text { Proportion of exposed people that be- } \\
\text { come infected }\end{array}$ & 0.5 & 0.9 & 1 & estimated & $-(7)$ & $3(3)$ \\
\hline$t_{i n c_{j}}$ & Incubation duration (in days) & 2 & 4.5 & 14 & {$[95,96]$} & $3(3)$ & $7(6)$ \\
\hline$t_{r e c}$ & Recovery duration (days) & 6 & 14 & 42 & {$[97-99]$} & $1(1)$ & $2(1)$ \\
\hline$C F R_{1}$ & Fatality rate for college population & 0.001 & 0.0092 & 0.016 & {$[97,100]$} & $-(-)$ & $1(-)$ \\
\hline$C F R_{2}$ & Fatality rate for community population & 0.01 & 0.06 & 0.15 & {$[101,102]$} & $-(5)$ & $-(2)$ \\
\hline$t_{i 2 d_{j}}$ & $\begin{array}{l}\text { Number of days from infection until } \\
\text { death }\end{array}$ & 14 & 35 & 56 & {$[99]$} & $-(8)$ & $4(4)$ \\
\hline
\end{tabular}

Table 1. Model parameters in Covid-19 campus- $\mathrm{X}$-community epidemic models, estimated values, and ranges used for parameter search and sensitivity analysis. "Rank order" indicates relative significance of each parameter on campus (community) outcomes (16 week totals); only statistically significant factors shown $(\alpha=.05)$.

\section{Reopening Scenario Analysis}

Common university reopening scenarios were identified from literature and published surveys, 19 generally belonging to one of several categories (Table 2); a recent New York Times survey (July 29, 2020) ${ }^{7}$ also summarized reopening plans of 271 U.S. colleges and universities. The most common approaches included primarily or fully in-person $(35 \%)$, primarily or fully online (32\%), and hybrid (19\%). For example, the University of Washington reopening plan ${ }^{103}$ illustrates a common approach wherein more than $90 \%$ of courses will be taught online, only with courses that cannot be taught remotely (e.g. medical and health sciences) taught in person with safety precautions; the majority of student services and advising will take place remotely, and any staff who can work remotely will continue to do so. In contrast, Purdue University illustrates an opposite approach ${ }^{104}$ wherein classes mainly will be taught on campus with contact precautions until Thanksgiving break and relying on students to manage their personal safety. 


\begin{tabular}{|c|c|c|c|}
\hline Intervention Description & Examples & Source & $\begin{array}{c}\text { Estimated } \\
\text { Reduction in } R_{0}\end{array}$ \\
\hline $\begin{array}{l}\text { Remote coursework for classes over } 50 \text {, testing, contact tracing, } \\
\text { health surveillance in dorms }\end{array}$ & $\begin{array}{l}\text { University of } \\
\text { Washington }\end{array}$ & {$[103,105]$} & $36 \%$ \\
\hline $\begin{array}{l}\text { Remote option available, social distancing, shortened semester, } \\
\text { flexible start dates for international students }\end{array}$ & Rice University & {$[106]$} & $25 \%$ \\
\hline $\begin{array}{l}\text { Face masks, social distancing, limited classes, some coursework } \\
\text { online, fewer students living on campus, shorter semester }\end{array}$ & Stanford University & [107] & $33 \%$ \\
\hline $\begin{array}{l}\text { More online classes, masks, social distancing, testing, health sur- } \\
\text { veillance, sanitizing and washing stations }\end{array}$ & Ohio State University & {$[108,109]$} & $30 \%$ \\
\hline $\begin{array}{l}\text { Some classes online, expanded housing, social distancing, face } \\
\text { masks, staggered hours, increased cleaning, testing, tracing }\end{array}$ & $\begin{array}{l}\text { Northeastern } \\
\text { University }\end{array}$ & {$[32,110]$} & $49 \%$ \\
\hline $\begin{array}{l}\text { Most classes online except those for which in-person instruction } \\
\text { is deemed necessary }\end{array}$ & $\begin{array}{l}\text { California State } \\
\text { Universities }\end{array}$ & {$[111,112]$} & $12 \%$ \\
\hline $\begin{array}{l}\text { Students back on campus for a shortened fall semester as long as } \\
\text { they follow CT reopening suggestions }\end{array}$ & $\begin{array}{l}\text { Connecticut State } \\
\text { Institutions }\end{array}$ & {$[113,114]$} & $46 \%$ \\
\hline
\end{tabular}

Table 2. Representative examples of university and college Covid-19 fall 2020 semester physical reopening plans.

For each scenario, 1,000 model replications were run for campus alone, community alone, and campus-X-community together to estimate additional cross-exposure impacts of each population on the other. For the campus-x-community cases, each of the 1,000 community parameterizations were randomly coupled with the 1,000 random sets of campus inputs, with the two populations interacting using 1,000 random values of the cross-exposure parameter, $r i_{j}$, sampled from the range shown in Table 1. Overall results (medians, standard deviations (SD), and 95\% probability intervals) and pairwise differences were computed for and between the 1,000 campus results and their campus-X-community counterparts, and similarly the 1,000 community results and their campus-X-community counterparts, in order to estimate attributable cross-exposure effects on community residents and students.

We assumed three geographic settings: (1) an urban campus of 10,000 students with 100,000 residents living the immediately surrounding residential areas or neighborhoods in which off-campus students tend to reside, (2) the same size student body $(10,000)$ but now with fewer $(40,000)$ residents living near campus, and (3) a smaller number of 2,000 students with 40,000 residents living near campus. The first scenario might represent a large university in a major city, whereas the second might represent a large rural university and the third a smaller undergraduate college in a non-urban setting. These student-to-community populations $(1: 10,1: 4,1: 20)$ can be extrapolated to other settings with similar ratios.

All results were tabulated, plotted longitudinally, and verified independently. First inflection points (dates of steepest increases) for each outcome, scenario, and population were identified numerically since in diffusion theory interventions after these points tend to be less effective. Sensitivity analyses were conducted to identify inputs to which results are most sensitive (via central composite factorial experimental designs ${ }^{115}$ ) as this could inform policy-making, interventions, and target setting. 


\section{Results}

\section{On-Campus/Student Impact}

Depending on Covid-19 prevalence among arriving students and semester initialization precautions, Figure 3 summarizes the predicted number of students per 10,000 who could be exposed, infectious, and die over. By semester end, under the base case ( $2 \%$ arrival prevalence, little returning precautions and/or effectiveness) student outcomes may range from 471 to 9,458 infections (median: 2,286, SD: 2,627) and 0 to 123 deaths (median: 9, SD: 14). The more realistic case ( $1 \%$ prevalence after intake) reduces these consequences to a median (SD) of $1,332(2,552)$ infections and 5 (12) deaths, with the greatest exposure and infection increases typically occurring at mid-semester onwards (with important implications on non-local spread as students return to their home communities).

While less likely, the idealistic $(0.1 \%)$ and worst-case $(5 \%)$ scenarios were included for reference comparison. The first would result in a median (SD) of $158(1,760)$ infections and $1(6)$ deaths, and the latter 3,996 $(2,485)$ infections and 16 (17) deaths. Under the base case, the total number of active student exposures that under a contact tracing approach should be identified range from 3 to 1,576 with implications on resource planning and viability. Under the two most likely scenarios (Table 3 ) by mid-semester consequences might reach as high (mean plus one standard deviation) as 810 infections and 4 deaths per 10,000 students, or conversely as low (mean minus one standard deviation) as 782 infections and 0 deaths.

\begin{tabular}{|c|c|c|c|c|c|c|c|c|c|c|c|c|}
\hline \multirow{2}{*}{ scenario } & \multicolumn{3}{|c|}{ September } & \multicolumn{3}{|c|}{ October } & \multicolumn{3}{|c|}{ November } & \multicolumn{3}{|c|}{ December } \\
\hline & Expo & Infect & Mort & Expo & Infect & Mort & Expo & Infect & Mort & Expo & Infect & Mort \\
\hline $\begin{array}{l}\text { Base } \\
\text { Case }\end{array}$ & $\begin{array}{c}474 \\
(175, \\
1840)\end{array}$ & $\begin{array}{c}318 \\
(146, \\
1181)\end{array}$ & $\begin{array}{c}1 \\
(0,3)\end{array}$ & $\begin{array}{c}708 \\
(160 \\
4731)\end{array}$ & $\begin{array}{c}510 \\
(131 \\
3561)\end{array}$ & $\begin{array}{c}2 \\
(1,11)\end{array}$ & $\begin{array}{c}925 \\
(124 \\
3532)\end{array}$ & $\begin{array}{c}685 \\
(105, \\
2946)\end{array}$ & $\begin{array}{c}3 \\
(0,16)\end{array}$ & $\begin{array}{c}638 \\
(74 \\
1934)\end{array}$ & $\begin{array}{c}522 \\
(63 \\
1576)\end{array}$ & $\begin{array}{c}2 \\
(0,12)\end{array}$ \\
\hline $\begin{array}{c}\text { Realistic } \\
\text { precau- } \\
\text { tions }\end{array}$ & $\begin{array}{c}245 \\
(89 \\
1011) \\
\end{array}$ & $\begin{array}{c}163 \\
(74,639)\end{array}$ & $\begin{array}{c}1 \\
(0,2)\end{array}$ & $\begin{array}{c}392 \\
(84 \\
3723) \\
\end{array}$ & $\begin{array}{c}278 \\
(68 \\
2777) \\
\end{array}$ & $\begin{array}{c}1 \\
(0,8)\end{array}$ & $\begin{array}{r}554 \\
(67 \\
4024) \\
\end{array}$ & $\begin{array}{c}411 \\
(56, \\
3304)\end{array}$ & $\begin{array}{c}2 \\
(0,14)\end{array}$ & $\begin{array}{c}504 \\
(41 \\
2279) \\
\end{array}$ & $\begin{array}{c}389 \\
(36 \\
1874) \\
\end{array}$ & $\begin{array}{c}2 \\
(0,12)\end{array}$ \\
\hline $\begin{array}{l}\text { Idealistic } \\
\text { precau- } \\
\text { tions }\end{array}$ & $\begin{array}{c}26 \\
(9,113)\end{array}$ & $\begin{array}{c}17 \\
(7,69)\end{array}$ & $\begin{array}{c}0 \\
(0,0)\end{array}$ & $\begin{array}{c}44 \\
(9,769)\end{array}$ & $\begin{array}{c}30 \\
(7,476)\end{array}$ & $\begin{array}{c}0 \\
(0,1)\end{array}$ & $\begin{array}{c}70 \\
(7,3072)\end{array}$ & $\begin{array}{c}49 \\
(6,2133)\end{array}$ & $\begin{array}{c}0 \\
(0,5)\end{array}$ & $\begin{array}{c}76 \\
(5,2997)\end{array}$ & $\begin{array}{c}56 \\
(4, \\
2366)\end{array}$ & $\begin{array}{c}0 \\
(0,8)\end{array}$ \\
\hline $\begin{array}{l}\text { Worst } \\
\text { case }\end{array}$ & $\begin{array}{l}1084 \\
(415, \\
3613)\end{array}$ & $\begin{array}{c}744 \\
(353, \\
2398)\end{array}$ & $\begin{array}{c}3 \\
(1,8)\end{array}$ & $\begin{array}{l}1377 \\
(354, \\
4623)\end{array}$ & $\begin{array}{l}1026 \\
(301, \\
3895)\end{array}$ & $\begin{array}{c}5 \\
(1,17)\end{array}$ & $\begin{array}{l}1225 \\
(248, \\
2840)\end{array}$ & $\begin{array}{c}994 \\
(221, \\
2380)\end{array}$ & $\begin{array}{c}5 \\
(1,19)\end{array}$ & $\begin{array}{c}624 \\
(122, \\
1406)\end{array}$ & $\begin{array}{c}537 \\
(114, \\
1214)\end{array}$ & $\begin{array}{c}3 \\
(1,12)\end{array}$ \\
\hline
\end{tabular}

Table 3. Predicted median number of monthly exposures, infections, and mortality per 10,000 students. Expo: exposures; Infect: infections; Mort: mortality. Values in parentheses indicate $95 \%$ probability ranges given uncertainties in many assumptions and inputs.

Figure 4 summarizes similar results assuming various semester-long operation precautions, with $25 \%-50 \%$ reductions plausible from effective testing, tracing, and isolation. In general, strategies to reduce exposure are very effective, as is intuitive, although under most scenarios a concerning number of students still can become infected or die. For example, in the very optimistic case with a $75 \%$ reduction in close contact, 95 to 132 infections (median: 107) and 1 death per 10,000 students may be likely by mid-semester, increasing to 97 to 139 infections and 0 to 3 deaths by semester end. 
medRxiv preprint doi: https://doi.org/10.1101/2020.08.29.20184366; this version posted September 13, 2020. The copyright holder for this preprint (which was not certified by peer review) is the author/funder, who has granted medRxiv a license to display the preprint in perpetuity.

All rights reserved. No reuse allowed without permission.

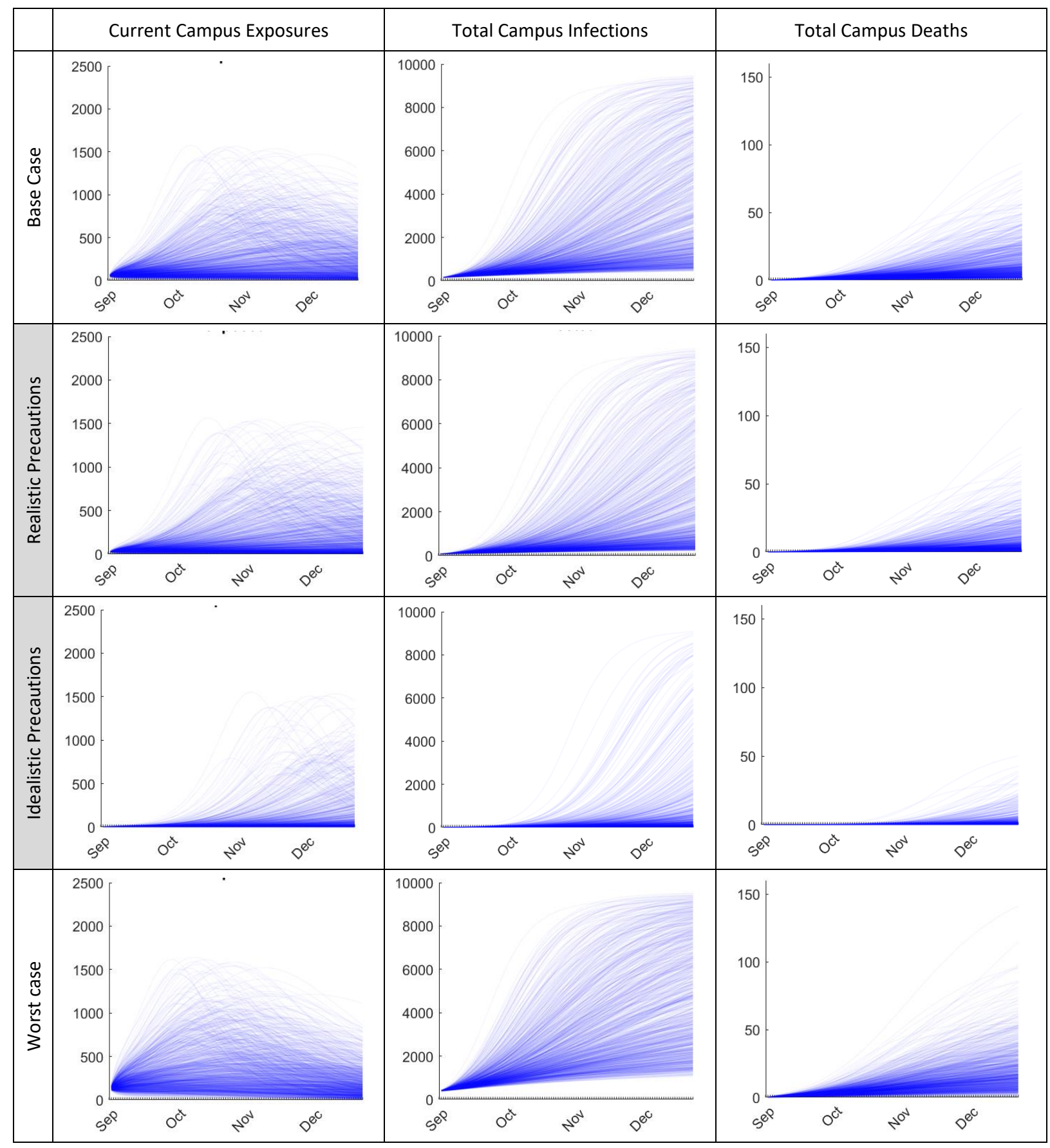

Figure 3. Predicted number of students per 10,000 who are currently exposed, total infected, and total mortality over a 16-week semester. Top row: base case scenario assuming no semester initiation precautions and disease prevalence of $2 \%$ among arriving students equal to national and regional averages.

Shaded middle rows (most likely cases): realistic (1\%) and idealistic $(0.1 \%)$ initial prevalence scenarios assuming good or great screening-on-arrival precautions, adherence, and effectiveness. Bottom row: worst case scenario (5\%) assuming home state rate increases and little-to-no arrival precautions, compliance, or effectiveness. 
medRxiv preprint doi: https://doi.org/10.1101/2020.08.29.20184366; this version posted September 13, 2020. The copyright holder for this preprint (which was not certified by peer review) is the author/funder, who has granted medRxiv a license to display the preprint in perpetuity.

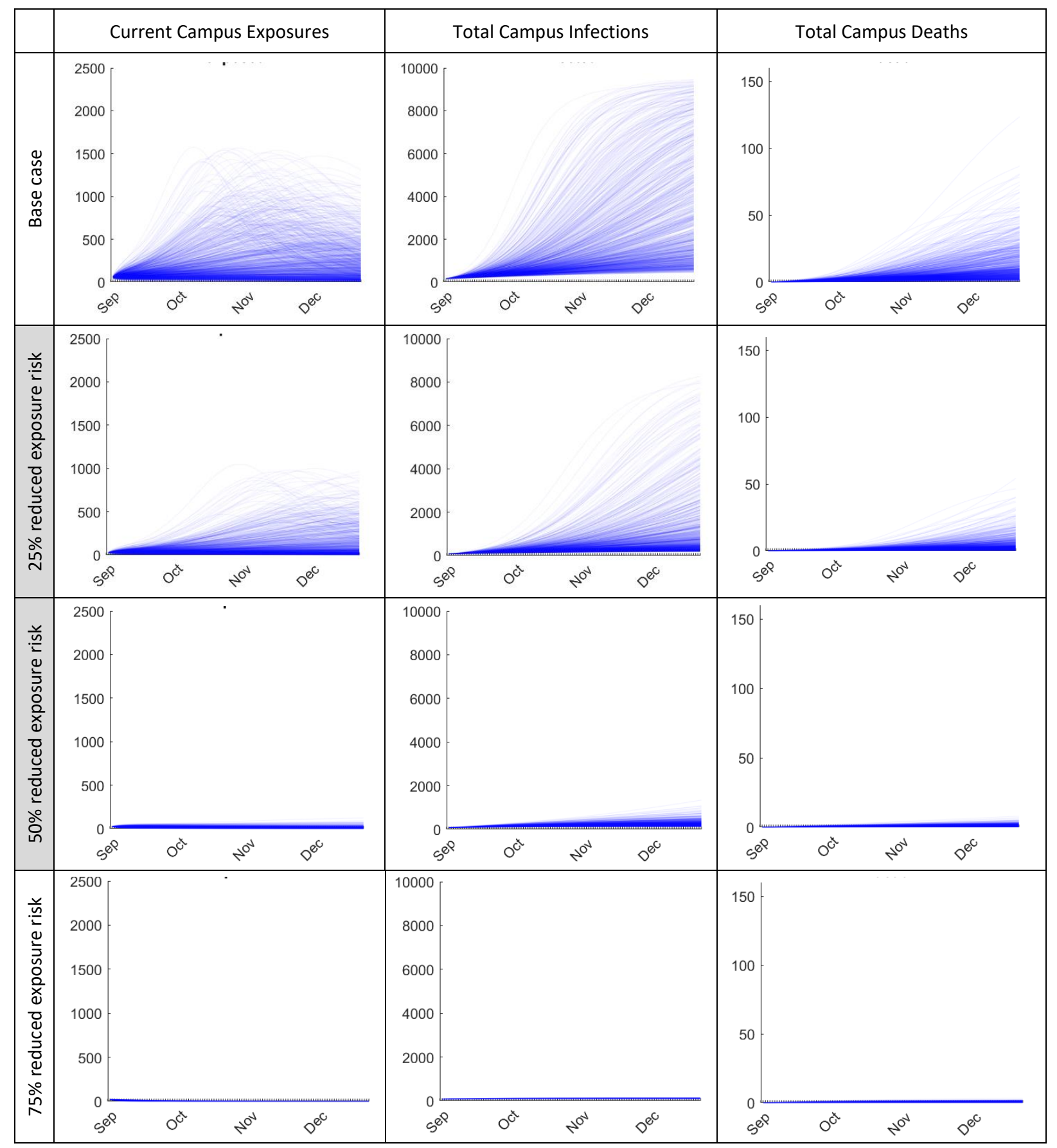

Figure 4. Relative effectiveness of reopening and precaution strategies on reducing campus exposures, infections, and mortality per 10,000 students (assuming 1\% of students are infected or exposed at the start of the semester). Top row: base case from Figure 3 for comparison; Shaded middle rows (most likely cases): realistic precaution effectiveness and compliance cases; Bottom row: idealistic precaution effectiveness and compliance. (Reduced exposure risk refers to reducing $R_{0}$.) 


\section{Community Resident Impact}

Figure 5 summarizes additional community (blue lines) and campus (red lines) impacts of reopening due to campus-X-community cross-exposure, assuming the same scenarios described above; for comparison the top row shows the baseline number of community exposures, infections, and mortality without reopening. The local community impacts (Table 4) of opening with little-to-no semester operation precautions and/or adherence might range from 1 to 9,768 additional community infections (median: 158, SD: 1,131) and 0 to 491 additional community deaths (median: 6, SD: 53).

The two more realistic scenarios result in a total of (for $25 \%$ exposure reduction) 1 to 5,577 additional community infections (median: 56, SD: 516) and 0 to 272 additional community deaths (median: 3, SD: 24), and (for 50\% exposure reduction) 0 to 464 additional community infections (median: 14, SD: 45) and 0 to 23 additional community deaths (median: 1, SD: 2). For completeness, the idealistic best-case scenario results in 0 to 33 additional community infections (median: 2, SD: 4) and 0 to 2 additional community deaths (median: 0, SD: 0.2).

\begin{tabular}{|c|c|c|c|c|c|c|c|c|c|c|c|c|}
\hline \multirow{2}{*}{$\begin{array}{c}\text { Scenario } \\
\text { (Exposure } \\
\text { Risk) }\end{array}$} & \multicolumn{3}{|c|}{ September } & \multicolumn{3}{|c|}{ October } & \multicolumn{3}{|c|}{ November } & \multicolumn{3}{|c|}{ December } \\
\hline & Expo & Infect & Mort & Expo & Infect & Mort & Expo & Infect & Mort & Expo & Infect & Mort \\
\hline \multicolumn{13}{|c|}{ a. Community Outcomes Assuming no University Interaction (per 10,000 ) } \\
\hline $\begin{array}{l}\text { Monthly } \\
\text { Totals }\end{array}$ & $\begin{array}{c}11 \\
(0,64)\end{array}$ & $\begin{array}{c}158 \\
(122,362)\end{array}$ & $\begin{array}{c}6 \\
(4,18)\end{array}$ & $\begin{array}{c}4 \\
(0,30)\end{array}$ & $\begin{array}{c}175 \\
(122,455)\end{array}$ & $\begin{array}{c}7 \\
(4,26)\end{array}$ & $\begin{array}{c}1 \\
(0,14)\end{array}$ & $\begin{array}{c}181 \\
(122,486)\end{array}$ & $\begin{array}{c}7 \\
(4,28)\end{array}$ & $\begin{array}{c}1 \\
(0,8)\end{array}$ & $\begin{array}{c}182 \\
(122,495)\end{array}$ & $\begin{array}{c}7 \\
(4,29)\end{array}$ \\
\hline \multicolumn{13}{|c|}{ b. Additional Community Outcomes Due to Reopening (total) } \\
\hline Base case & $\begin{array}{c}6 \\
(1,24)\end{array}$ & $\begin{array}{c}9 \\
(2,26)\end{array}$ & $\begin{array}{c}0 \\
(0,1)\end{array}$ & $\begin{array}{c}11 \\
(1,69)\end{array}$ & $\begin{array}{c}32 \\
(6,126)\end{array}$ & $\begin{array}{c}1 \\
(0,4)\end{array}$ & $\begin{array}{c}13 \\
(1,148)\end{array}$ & $\begin{array}{c}78 \\
(10,415)\end{array}$ & $\begin{array}{c}3 \\
(0,10)\end{array}$ & $\begin{array}{c}14 \\
(1,180)\end{array}$ & $\begin{array}{c}124 \\
(14,755)\end{array}$ & $\begin{array}{c}5 \\
(1,19)\end{array}$ \\
\hline $\begin{array}{c}25 \% \\
\text { reduced } \\
\text { exposure }\end{array}$ & $\begin{array}{c}3 \\
(1,14)\end{array}$ & $\begin{array}{c}6 \\
(2,17)\end{array}$ & $\begin{array}{c}0 \\
(0,1)\end{array}$ & $\begin{array}{c}4 \\
(0,23)\end{array}$ & $\begin{array}{c}17 \\
(4,56)\end{array}$ & $\begin{array}{c}1 \\
(0,2)\end{array}$ & $\begin{array}{c}6 \\
(0,42)\end{array}$ & $\begin{array}{c}32 \\
(5,147)\end{array}$ & $\begin{array}{c}1 \\
(0,5)\end{array}$ & $\begin{array}{c}6 \\
(0,57)\end{array}$ & $\begin{array}{c}48 \\
(7,263)\end{array}$ & $\begin{array}{c}2 \\
(0,7)\end{array}$ \\
\hline $\begin{array}{c}50 \% \\
\text { reduced } \\
\text { exposure }\end{array}$ & $\begin{array}{c}1 \\
(0,4)\end{array}$ & $\begin{array}{c}3 \\
(1,7)\end{array}$ & $\begin{array}{c}0 \\
(0,0)\end{array}$ & $\begin{array}{c}1 \\
(0,3)\end{array}$ & $\begin{array}{c}6 \\
(1,16)\end{array}$ & $\begin{array}{c}0 \\
(0,1)\end{array}$ & $\begin{array}{c}1 \\
(0,3)\end{array}$ & $\begin{array}{c}9 \\
(2,23)\end{array}$ & $\begin{array}{c}0 \\
(0,1)\end{array}$ & $\begin{array}{c}0 \\
(0,2)\end{array}$ & $\begin{array}{c}10 \\
(2,29)\end{array}$ & $\begin{array}{c}1 \\
(0,1)\end{array}$ \\
\hline $\begin{array}{c}75 \% \\
\text { reduced } \\
\text { exposure }\end{array}$ & $\begin{array}{c}0 \\
(0,1)\end{array}$ & $\begin{array}{c}1 \\
(0,2)\end{array}$ & $\begin{array}{c}0 \\
(0,0)\end{array}$ & $\begin{array}{c}0 \\
(0,0)\end{array}$ & $\begin{array}{c}1 \\
(0,3)\end{array}$ & $\begin{array}{c}0 \\
(0,0)\end{array}$ & $\begin{array}{c}0 \\
(0,0)\end{array}$ & $\begin{array}{c}1 \\
(0,4)\end{array}$ & $\begin{array}{c}0 \\
(0,0)\end{array}$ & $\begin{array}{c}0 \\
(0,0)\end{array}$ & $\begin{array}{c}1 \\
(0,4)\end{array}$ & $\begin{array}{c}0 \\
(0,0)\end{array}$ \\
\hline \multicolumn{13}{|c|}{ c. Additional University Outcomes Due to Reopening (total) } \\
\hline Base case & $\begin{array}{c}0 \\
(0,5)\end{array}$ & $\begin{array}{c}1 \\
(0,10)\end{array}$ & $\begin{array}{c}0 \\
(0,0)\end{array}$ & $\begin{array}{c}1 \\
(0,8)\end{array}$ & $\begin{array}{c}3 \\
(0,30)\end{array}$ & $\begin{array}{c}0 \\
(0,0)\end{array}$ & $\begin{array}{c}0 \\
(0,10)\end{array}$ & $\begin{array}{c}5 \\
(0,56)\end{array}$ & $\begin{array}{c}0 \\
(0,0)\end{array}$ & $\begin{array}{c}0 \\
(0,8)\end{array}$ & $\begin{array}{c}6 \\
(0,76)\end{array}$ & $\begin{array}{c}0 \\
(0,0)\end{array}$ \\
\hline $\begin{array}{c}25 \% \\
\text { reduced } \\
\text { exposure }\end{array}$ & $\begin{array}{c}0 \\
(0,4)\end{array}$ & $\begin{array}{c}1 \\
(0,9)\end{array}$ & $\begin{array}{c}0 \\
(0,0)\end{array}$ & $\begin{array}{c}0 \\
(0,5)\end{array}$ & $\begin{array}{c}2 \\
(0,22)\end{array}$ & $\begin{array}{c}0 \\
(0,0)\end{array}$ & $\begin{array}{c}1 \\
(0,5)\end{array}$ & $\begin{array}{c}3 \\
(0,36)\end{array}$ & $\begin{array}{c}0 \\
(0,0)\end{array}$ & $\begin{array}{c}0 \\
(0,5)\end{array}$ & $\begin{array}{c}4 \\
(0,46)\end{array}$ & $\begin{array}{c}0 \\
(0,0)\end{array}$ \\
\hline $\begin{array}{c}50 \% \\
\text { reduced } \\
\text { exposure }\end{array}$ & $\begin{array}{c}0 \\
(0,3)\end{array}$ & $\begin{array}{c}1 \\
(0,7)\end{array}$ & $\begin{array}{c}0 \\
(0,0)\end{array}$ & $\begin{array}{c}0 \\
(0,2)\end{array}$ & $\begin{array}{c}1 \\
(0,14)\end{array}$ & $\begin{array}{c}0 \\
(0,0)\end{array}$ & $\begin{array}{c}0 \\
(0,1)\end{array}$ & $\begin{array}{c}1 \\
(0,19)\end{array}$ & $\begin{array}{c}0 \\
(0,0)\end{array}$ & $\begin{array}{c}0 \\
(0,1)\end{array}$ & $\begin{array}{c}2 \\
(0,21)\end{array}$ & $\begin{array}{c}0 \\
(0,0)\end{array}$ \\
\hline $\begin{array}{c}75 \% \\
\text { reduced } \\
\text { exposure }\end{array}$ & $\begin{array}{c}0 \\
(0,2)\end{array}$ & $\begin{array}{c}1 \\
(0,6)\end{array}$ & $\begin{array}{c}0 \\
(0,0)\end{array}$ & $\begin{array}{c}0 \\
(0,1)\end{array}$ & $\begin{array}{c}1 \\
(0,11)\end{array}$ & $\begin{array}{c}0 \\
(0,0)\end{array}$ & $\begin{array}{c}0 \\
(0,0)\end{array}$ & $\begin{array}{c}1 \\
(0,13)\end{array}$ & $\begin{array}{c}0 \\
(0,0)\end{array}$ & $\begin{array}{c}0 \\
(0,0)\end{array}$ & $\begin{array}{c}1 \\
(0,13)\end{array}$ & $\begin{array}{c}0 \\
(0,0)\end{array}$ \\
\hline
\end{tabular}

Table 4. Predicted monthly total community outcomes (per 10,000) assuming (a) no university interaction, (b) additional community resident outcomes, and (c) additional university student outcomes. Expo: exposures; Infect: infections; Mort: mortality. Tabulated values are medians; parentheses indicate 95\% probability ranges given the noted uncertainties in many assumptions and inputs. 
medRxiv preprint doi: https://doi.org/10.1101/2020.08.29.20184366; this version posted September 13, 2020. The copyright holder for this preprint (which was not certified by peer review) is the author/funder, who has granted medRxiv a license to display the preprint in perpetuity.

All rights reserved. No reuse allowed without permission.

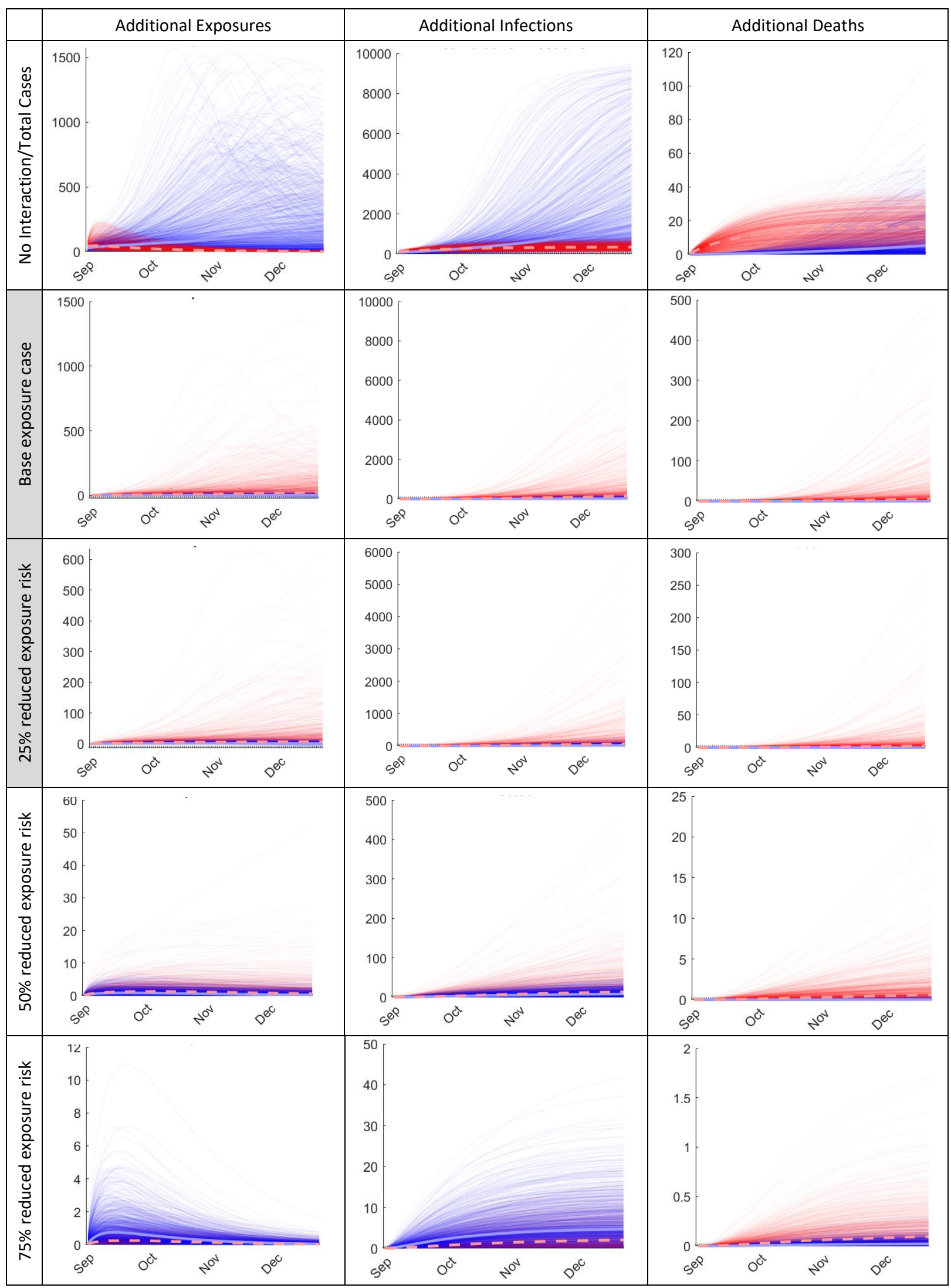


medRxiv preprint doi: https://doi.org/10.1101/2020.08.29.20184366; this version posted September 13, 2020. The copyright holder for this preprint (which was not certified by peer review) is the author/funder, who has granted medRxiv a license to display the preprint in perpetuity. All rights reserved. No reuse allowed without permission.

Figure 5. Additional (red) community and (blue) campus exposures, infections, and mortality due to community-X-campus cross-exposure (prevalence among arriving students varied between $0.1 \%$ to $2 \%$ ). No interaction: total outcomes assuming no interaction between school and community). Base case: addi$\underline{\text { tional }}$ outcomes due to campus reopening assuming little-to-no campus semester operation precautions, compliance, or effectiveness. Shaded rows (most likely cases): additional outcomes assuming likely and ideal cases for campus operation precautions, adherence, and effectiveness. Bottom row: additional outcomes under best case scenario assuming very high campus semester operation precautions, compliance, and effectiveness.

The corresponding impact of the community on student outcomes ranges from, for the base case, in a total of 0 to 390 additional student infections (median: 21, SD: 38) and 0 to 2 additional student deaths (median: 0, SD: 0.2) to 0 to 42 additional student infections (median: 5, SD: 6) and 0 additional student deaths (median: 0, SD: 0.04) for the idealistic case (75\% exposure reduction). The two more likely cases result in (for $25 \%$ exposure reduction) 0 to 279 additional student infections (median: 17, SD: 30) and 0 to 1 additional student deaths (median: 0, SD: 0.1), and (for $50 \%$ exposure reduction) 0 to 115 additional student infections (median: 8, SD: 12) and 0 to 1 additional student deaths (median: 0, SD: 0.06).

To estimate the impact of school size and location (urban, rural), Figure 6 compares results under other student-to-community population sizes, assuming the same realistic arrival prevalence and campus operation precautions, compliance, and effectiveness scenarios. While differences intuitively exist in raw totals, results are similar and scale-invariant after adjusted for population size. For example, multiplying results by 2.5 for the second case of 40,000 residents produces similar curves to those for the first case of 100,000 residents. Insights from most above results therefore can be viewed as generalizable to many other settings until further analyses can be conducted for any specific university and city size.

Finally, factorial sensitivity analysis produced the relative parameter rankings shown in Table 2, which follow intuition and serve as further model validation. The most important statistically significant factors (main effects) affecting total campus infections were recovery time, $R_{0, \text { campus }}$, in-

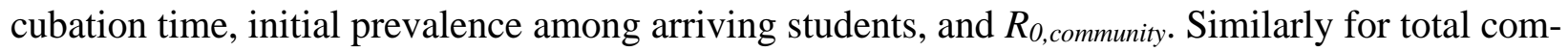
munity infections, the most significant factors were recovery time, $R_{0, \text { community }}$, incubation time, initial prevalence among community residents, $R_{0 \text {,campus }}, p_{j}$, infection-to-death duration, and campus-community cross-exposure. Numerous interaction terms also were significant in both cases, as would be expected in such a model. Similar results for mortality are summarized in the rightmost column of Table 2 . 
medRxiv preprint doi: https://doi.org/10.1101/2020.08.29.20184366; this version posted September 13, 2020. The copyright holder for this preprint (which was not certified by peer review) is the author/funder, who has granted medRxiv a license to display the preprint in perpetuity.

All rights reserved. No reuse allowed without permission.

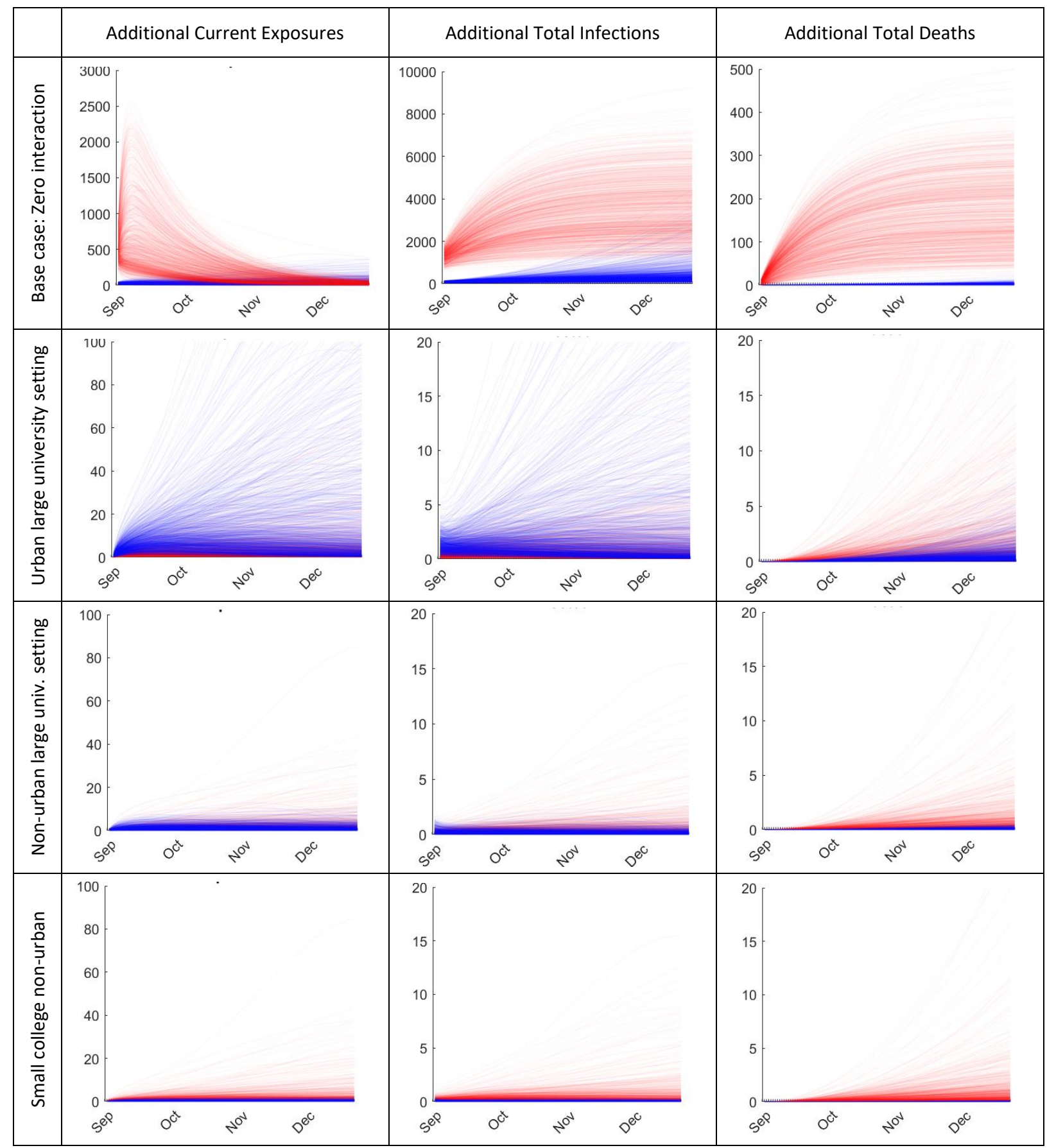

Figure 6. Impact of school-to-community population sizes on predicted additional community resident (red) and student (blue) current exposures, total infections, and total deaths per 10,000 individuals, assuming $1 \%$ prevalence among returning students and effective campus operations precautions $\left(50 \% R_{0}\right.$ reduction). Urban large university: 10,000 students, 100,000 community residents; Non-urban large university: 10,000 students, 40,000 community residents; Small college non-urban: 2,000 students, 40,000 community residents. 
medRxiv preprint doi: https://doi.org/10.1101/2020.08.29.20184366; this version posted September 13, 2020. The copyright holder for this

\section{Discussion}

The Covid-19 pandemic continues to be a significant public health crisis, with infections and mortality in many regions meeting or exceeding those in early 2020 before physical distancing and work/school closures were implemented. With many colleges and universities reconsidering opening plans over the next several semesters, model-based analyses can help inform these important decisions. The large number of institutions that already reversed fall 2020 decisions also underscores this importance.

Perhaps the most important insight from results is that predicted infections and mortality from campus reopening are highly variable due to a combination of random chance, input, scenario, effectiveness, and compliance assumptions. Predicting results with any certainty is nearly impossible, despite some assurances otherwise. While regular (pre-Covid-19) campus operations could be disastrous, community and student harm even under best-case scenarios still could occur. Several other important implications exist.

First, decisions whether to open in future academic terms should include updated model inputs, understanding of dynamics, and projections of local conditions. While conditions may exist under which reopening is relatively safe, at the present time these appear in the minority. Since any trajectory within current model intervals could occur by definition, reopening decisions also should consider these ranges rather (than averages alone, which are less relevant without their probabilistic context).

Second, clear criteria should be established under which a campus should tighten policies or close altogether, including contingency plans and methods for rapidly detecting when such conditions are approaching. Absent these a priori, any campus reopening might be considered a breach of public trust if not negligent. Since it appears probable that at some point during the fall 2020 semester many schools may need to transition to fully virtual operations, families and public health officials should plan accordingly. A related concern is infections that might be caused elsewhere by students traveling home after the SARS-CoV-2 virus has spread among them, underscoring the importance of rapid trend detection and action.

Third, contact tracing infrastructure and effectiveness should be examined and aggressively addressed if needed. In many scenarios, large numbers of potential exposures may occur weekly, possibly exceeding some university timely tracing capabilities. While many schools report creating impressive test capacities, whether sufficient capacity exists then to trace contacts is unclear - presupposing detected positive students can (or are willing to) identify most contacts including community interactions. Revisiting whether sufficient isolated living space exists for detected positive students, based on predicted weekly infections, also may be important.

Finally, given likely similar uncertainties at least through the next few academic terms, viable alternatives to 16-week on-campus semesters might be further developed, as some have proposed. In other socioeconomic sectors, most notably healthcare, Covid-19 disruptions resulted in creation and refinement of significantly new ways to meet needs, some being improvements that continue to evolve over time. Strong and similar motivations may exist to re-invent a large and important sector of society. 
medRxiv preprint doi: https://doi.org/10.1101/2020.08.29.20184366; this version posted September 13, 2020. The copyright holder for this

Like any model-based analysis, results herein have some limitations and simplifications. A common barrier in such models is data availability for input estimation and results validation (hence our search-based approach). The deterministic ODE modeling framework ignores inherent variability and population heterogeneity, ${ }^{116}$ motivating our use of Monte Carlo analysis, parameter search repetitions, and varied scenarios. Standard model simplifications include limiting the number of populations (e.g., one overall homogenous community or student population), limiting spread to just SARS-CoV-2 (e.g., ignoring seasonal influenza, the substance abuse co-epidemic, 75,76 and co-spread impacts), and not time-varying precaution compliance as concerns and vigilance relax or heighten over time. Some scenarios also were included for potential insights rather than being feasible in practice (e.g., $75 \%$ reduction in $R_{0}$, near $100 \%$ precaution compliance). Results nonetheless offer valuable insights into the range of potential community and student impacts, intervention effectiveness, and inflection criteria at which, if approaching, campuses should close.

Further work could expand on these results, including addressing some of the above simplifications made in the interest of time. Work also could occur to determine combined conditions (reduced prevalence, vaccine effectiveness, improved precaution methods, etc.) under which outcomes are both safer and more certain. City- or state-wide decision-making also might be considered in the future, such as coordinating across schools to alternate on-campus periods or limiting combined student densities to reduce net community impacts.

\section{Conclusion}

Controlling the Covid-19 pandemic over the next several semesters is extremely critical. Computer models can offer valuable insights to important decisions, including potential community and campus impacts from university reopening. The analysis summarized herein underscores three key points: (1) exact outcomes over a 16-week semester can differ significantly under different assumptions and by chance alone, (2) off-campus impacts on local community residents could be significant, and (3) even under the best assumptions outcomes appear fairly uncertain but with near certainty non-zero. Similar analyses thus might investigate alternate approaches to provide valuable university education models until spread is better controlled.

\section{Acknowledgements}

This research was supported in part by the National Science Foundation (CMMI-1742521) and National Institute of Drug Abuse (R21DA046776-01). The content is solely the responsibility of the authors and does not represent official views of either funder. The authors thank Basma Bargal for help with references. 
medRxiv preprint doi: https://doi.org/10.1101/2020.08.29.20184366; this version posted September 13, 2020. The copyright holder for this preprint (which was not certified by peer review) is the author/funder, who has granted medRxiv a license to display the preprint in perpetuity.

\section{References}

1. World Health Organization. WHO Coronavirus Disease (COVID-19) Dashboard. 2020; https://covid19.who.int/.

2. Bonaccorsi G, Pierri F, Cinelli M, et al. Economic and social consequences of human mobility restrictions under COVID-19. Proceedings of the National Academy of Sciences. 2020;117(27):15530-15535.

3. Whitney P. Racial capitalism: A fundamental cause of novel coronavirus (COVID-19) pandemic inequities in the United States. Health Education and Behavior. 2020;47 (4):504-508.

4. Di Renzo L, Gualtieri P, Pivari F, et al. Eating habits and lifestyle changes during COVID-19 lockdown: an Italian survey. Journal of Translational Medicine. 2020;18(1):1-15.

5. Baker SR, Bloom N, Davis SJ, Terry SJ. Covid-induced economic uncertainty. National Bureau of Economic Research;2020. 0898-2937.

6. Michael S. Colleges Are Deluding Themselves. May 15, 2020.

7. Weiyi CD, Ivory; Mitch, Smith; Alex, Lemonides; Lauryn, Higgins;. More Than 6,600 Coronavirus Cases Have Been Linked to U.S. Colleges. The New York Times. July 29, 2020.

8. Yascha M. Cancel College: Reopening universities will accomplish little and endanger many. August 8, 2020.

9. Panovska-Griffiths J, Kerr CC, Stuart RM, et al. Determining the optimal strategy for reopening schools, the impact of test and trace interventions, and the risk of occurrence of a second COVID-19 epidemic wave in the UK: a modelling study. The Lancet Child and Adolescent Health. 2020.

10. Vermund SH, Pitzer VE. Asymptomatic transmission and the infection fatality risk for COVID-19: Implications for school reopening. Clinical Infectious Diseases. 2020.

11. Di Domenico L, Pullano G, Sabbatini CE, Boëlle P-Y, Colizza V. Expected impact of reopening schools after lockdown on COVID-19 epidemic in Île-de-France. medRxiv. 2020.

12. Cassell R. Downs M, Halamka J, Kansagra S, Partners L, Palekar R, Ramaraju N, Rambhia K, Rudy K, Schnitzer J, Wilkerson T. Planning For On-Campus K-12 Education During Covid-19. Healthcare Coalition;2020.

13. Bond E, Dibner K, Schweingruber H. Reopening K-12 Schools During the COVID-19 Pandemic: Prioritizing Health, Equity, and Communities. Washington, DC, 2020.

14. Graeme W. There's No Simple Way to Reopen Universities. In: The Atlantic, 2020

15. Erin D. College enrollment in the United States from 1965 to 2018 and projections up to 2029 for public and private colleges 2020; https://www.statista.com/statistics/183995/us-college-enrollmentand-projections-in-public-and-private-institutions/.

16. Barton DC. Impacts of the COVID-19 pandemic on field instruction and remote teaching alternatives: Results from a survey of instructors. Ecology and evolution. 2020.

17. North R, Vitto C, Hickam G, Santen SA, Messman A. Remote Learning in the Time of COVID-19. AEM education and training. 2020;4(3):280-283.

18. Gross LM. Learning Together During the COVID-19 Experience. Journal - American Water Works Association. 2020;112(8):81-83. 
medRxiv preprint doi: https://doi.org/10.1101/2020.08.29.20184366; this version posted September 13, 2020. The copyright holder for this preprint (which was not certified by peer review) is the author/funder, who has granted medRxiv a license to display the preprint in perpetuity. All rights reserved. No reuse allowed without permission.

19. The Chronicle of Higher Education. Here's Our List of Colleges' Reopening Plans 2020; https://www.chronicle.com/article/Here-s-a-List-of-Colleges248626?bc_nonce=8pp81a34069hr195uggyf\&cid=reg_wall_signup.

20. Hai D. Largest University System in US, Cal State, Moves Fall Classes Online VOA News. May 13, 2020 .

21. Weeden K, Cornwell B. The Small-World Network of College Classes: Implications for Epidemic Spread on a University Campus. Sociological science. 2020;7(9):222-241.

22. Chris Q. COVID-19 will hit colleges when students arrive for fall semester. So why open at all? Money is a factor. USA Today. August 17, 2020.

23. Duan M, Janmohamed A, Wan J, Zhang Y, Henderson S, Shmoys D, Frazier P. COVID-19 Mathematical Modeling for Cornell's Fall Semester. Cornell University; June 15, 2020.

24. Jyoti M. 'Ethically troubling.' University reopening plans put professors, students on edge. In. Science. American Association For the Advancement of Science 2020.

25. Shweta BC, Carlson; John, Kraemer;. There is no safe way to reopen colleges this fall, The Washington Post. June 30, 2020.

26. Emma W. August Wave of Campus Reopening Reversals. Inside Higher Ed. August 12, 2020.

27. Joey H. What The Top 25 Colleges and Universities In The US Have Said About Their Plans to Reopen In Fall 2020, From Postponing The Semester To Offering More Remote Coursework. Business Insider. July 28, 2020.

28. Ron K. Stanford's plan for fall quarter: Most classes online, half the students on campus. San Francisco Chronicle. June 29, 2020.

29. Elinor AS, Zwickel; In Person, Online Classes or A Mix: Colleges' Fall 2020 Coronavirus Reopening Plans, Detailed. USA Today. June 22, 2020.

30. Emily BZ, Murdock;. UConn revokes on-campus housing for students captured on video partying in a packed dorm room without face masks. Hartford Courant. August 18, 2020.

31. Emily C. BU Should Go Fully Online This Fall BU Today. July 9, 2020.

32. Northeastern University. Reopening Northeastern. 2020; https://news.northeastern.edu/coronavirus/.

33. Hellewell J, Abbott S, Gimma A, et al. Feasibility of controlling COVID-19 outbreaks by isolation of cases and contacts. Lancet Glob Health. 2020;8(4):e488-e496.

34. Oran DP, Topol EJ. Prevalence of Asymptomatic SARS-CoV-2 Infection: A Narrative Review. Annals of Internal Medicine. 2020.

35. Brüssow H. COVID-19: test, trace and isolate-new epidemiological data. Environmental Microbiology. 2020;22(7):2445-2456.

36. Lauer SA, Grantz KH, Bi Q, et al. The Incubation Period of Coronavirus Disease 2019 (Covid-19) from Publicly Reported Confirmed Cases: Estimation and Application. Annals of Internal Medicine. 2020;172(9):577-582.

37. Harvard Health Publishing. If You've Been Exposed to The Coronavirus 2020; https://www.health.harvard.edu/diseases-and-conditions/if-youve-been-exposed-to-the-coronavirus.

38. Mitch A. Young people and bars are a recipe for coronavirus. The Daily Herald. June 29, 2020.

39. Caroline K. Virginia Tech confirms five total positive COVID-19 cases ahead of first day of classes ABC News. August 18, 2020. 
medRxiv preprint doi: https://doi.org/10.1101/2020.08.29.20184366; this version posted September 13, 2020. The copyright holder for this preprint (which was not certified by peer review) is the author/funder, who has granted medRxiv a license to display the preprint in perpetuity. All rights reserved. No reuse allowed without permission.

40. Wilson W. UNC-Chapel Hill goes to remote learning after 135 COVID-19 cases within week of starting classes. NBC News. August 18, 2020.

41. Bono G, Reil K, Hescox J. Stress and wellbeing in urban college students in the US during the COVID-19 pandemic: Can grit and gratitude help? International Journal of Wellbeing. 2020;10(3).

42. Gurukkal R. Will COVID 19 Turn Higher Education into Another Mode? Higher Education for the Future. 2020;7(2):89-96.

43. Catherine T. Why coronavirus-battered universities may not be able to use their endowments. $A B C$ News. April 25, 2020.

44. Lee G. Colleges Face a No-Win Dilemma: To Cut or Not to Cut Tuition? Chronicle of Higher Education. July 15, 2020.

45. Cameron M. How COVID- 19 Can Reinvent Higher Education. May 5, 2020.

46. Sullivan R. College Towns and COVID-19: The Impact on New England. In: Federal Reserve Bank of Boston; 2020.

47. Viner RM, Bonell C, Drake L, et al. Reopening schools during the COVID-19 pandemic: governments must balance the uncertainty and risks of reopening schools against the clear harms associated with prolonged closure. Archives of disease in childhood. 2020, archdischild-2020-319963.

48. Andrew D. Here's A Look At The Impact Of Coronavirus (COVID-19) On Colleges And Universities In The U.S. Forbes. April 30, 2020.

49. Doug L. Low-Income Students Top Presidents' COVID-19 Worry List. Inside Higher Ed. April 27, 2020.

50. Doug L. COVID-19's Forceful Financial Hit: A Survey of Business Officers. Inside Higher Ed. July 10, 2020, 2020.

51. Gabriella BN, Layne;. North Carolina university is latest U.S. school to roll back campus reopening. Reuters. August 17, 2020.

52. Tracking COVID-19 at Notre Dame. The Observer. August 15, 2020.

53. William M, Samara L. Significant number of Navy midshipmen test positive on return to school. ABC News. August 15, 2020.

54. Rachel T. Michigan State And Notre Dame Suspend In-Person Learning Over COVID-19 Concerns. NPR. August 18, 2020.

55. Athena J. 19 states see Covid-19 outbreaks on college campuses. 2020; https://www.cnn.com/videos/health/2020/08/21/coronavirus-daily-wrap-colleges-vaccine-jones-dntlead-vpx.cnn.

56. High Schools Scramble to Contain Coronavirus outbreaks. CBS, 2020.

57. Lois P. "This is exactly what we've been warning about": Why some school reopenings have backfired. In: Vox, 2020.

58. David A. At least 31 percent of children tested in Florida are positive for COVID-19: report. FOX News. July 15, 2020.

59. Public Affairs. Social Gatherings Produce Increase in Student Covid-19 Cases. https://news.berkeley.edu/2020/07/08/social-gatherings-produce-increase-in-student-covid-19cases/. 
medRxiv preprint doi: https://doi.org/10.1101/2020.08.29.20184366; this version posted September 13, 2020. The copyright holder for this preprint (which was not certified by peer review) is the author/funder, who has granted medRxiv a license to display the preprint in perpetuity. All rights reserved. No reuse allowed without permission.

60. Zachariah P, Johnson CL, Halabi KC, et al. Epidemiology, Clinical Features, and Disease Severity in Patients With Coronavirus Disease 2019 (COVID-19) in a Children's Hospital in New York City, New York. JAMA pediatrics. 2020:e202430.

61. Liu Y, Gu Z, Xia S, et al. What are the underlying transmission patterns of COVID-19 outbreak? An age-specific social contact characterization. EClinicalMedicine. 2020;22:100354.

62. Kristin M. What Should I Know About Coronavirus and Children? In. WCVB-TV channel 5: Boston Children's Hospital; 2020.

63. Prosper O, Saucedo O, Thompson D, Torres-Garcia G, Wang X, Castillo-Chavez C. Modeling control strategies for concurrent epidemics of seasonal and pandemic H1N1 influenza. Mathematical Biosciences Engineering. 2011;8(1):141.

64. Choi YH, Jit M, Flasche S, Gay N, Miller E. Mathematical modelling long-term effects of replacing Prevnar7 with Prevnar13 on invasive pneumococcal diseases in England and Wales. PLoS One. 2012;7(7):e39927.

65. Mishra S, Pickles M, Blanchard JF, Moses S, Shubber Z, Boily M-C. Validation of the modes of transmission model as a tool to prioritize HIV prevention targets: a comparative modelling analysis. PLoS One. 2014;9(7):e101690.

66. Yang Z, Zeng Z, Wang K, et al. Modified SEIR and AI prediction of the epidemics trend of COVID19 in China under public health interventions. J Thorac Dis. 2020;12(3):165-174.

67. Kermack WO, McKendrick AG. A contribution to the mathematical theory of epidemics. Proceedings of The Royal Society Of London. 1927;115(772):700-721.

68. Hoppenstaedt F. Mathematical theories of populations: demographics, genetics and epidemics. SIAM; 1975.

69. Ramli M, Chaira Zulfa S, Ayuningtia Chaniago N, Halfiani V. Mathematical analysis on SEIR-type model of the Tuberculosis disease spread with vaccination and treatment elements. Journal of physics Conference series. 2019;1235:12120.

70. Side S, Mulbar U, Sidjara S, Sanusi W. A SEIR model for transmission of tuberculosis. Paper presented at: AIP2017.

71. Dantas E, Tosin M, Cunha Jr A. Calibration of a SEIR-SEI epidemic model to describe the Zika virus outbreak in Brazil. Applied Mathematics and Computation. 2018;338:249-259.

72. McGee A. Zika Virus Transmission Using Two Overlapping SEIR Models. In: ProQuest Dissertations Publishing; 2018.

73. Lekone PE, Finkenstädt BF. Statistical Inference in a Stochastic Epidemic SEIR Model with Control Intervention: Ebola as a Case Study. Biometrics. 2006;62(4):1170-1177.

74. Wakeland W, Nielsen A, Schmidt TD. System dynamics modeling of medical use, nonmedical use and diversion of prescription opioid analgesics. Paper presented at: 30th International System Dynamics Conference2012; St. Gallen, Switzerland.

75. Wayne W, Alexandra N, Teresa DS, et al. Modeling the Impact of Simulated Educational Interventions on the Use and Abuse of Pharmaceutical Opioids in the United States: A Report on Initial Efforts. Health Educ Behav. 2013;40(1_suppl):74S-86S.

76. White E, Comiskey C. Heroin epidemics, treatment and ODE modelling. Math Biosci. 2007;208(1):312-324.

77. Kang H, Wang Y, Tong Z, Liu X. Retest Positive for SARS-CoV-2 RNA of "Recovered" Patients with COVID-19: Persistence, Sampling Issues, or Re-infection? Journal of Medical Virology. 2020. 
medRxiv preprint doi: https://doi.org/10.1101/2020.08.29.20184366; this version posted September 13, 2020. The copyright holder for this preprint (which was not certified by peer review) is the author/funder, who has granted medRxiv a license to display the preprint in perpetuity.

All rights reserved. No reuse allowed without permission.

78. Naylor TH, Finger JM. Verification of Computer Simulation Models. Management Science. 1967;14(2):B-92-B-101.

79. Law AM. Simulation Modeling and Analysis. 2nd ed. New York: McGraw-Hill; 1991.

80. McHale M, Friedman J, Karian J. Standard for verification and validation in computational fluid dynamics and heat transfer. The American Society of Mechanical Engineers. 2009:20-2009.

81. Sargent RG. A New Statistical Procedure for Validation of Simulation and Stochastic Models. Syracuse, New York: Syracuse University;2010.

82. North American CRO Council. Model Validation Principles Applied to Risk and Capital Models in the Insurance Industry. 2012; http://www.crocouncil.org/images/CRO Council -

Model Validation Principles.pdf.

83. Edlund S, Kaufman J, Lessler J, et al. Comparing three basic models for seasonal influenza. Epidemics. 2011;3(3):135-142.

84. González-Parra G, Arenas AJ, Aranda DF, Segovia L. Modeling the epidemic waves of AH1N1/09 influenza around the world. Spatial and spatio-temporal epidemiology. 2011;2(4):219-226.

85. Venkatramanan S, Lewis B, Chen J, Higdon D, Vullikanti A, Marathe M. Using data-driven agentbased models for forecasting emerging infectious diseases. Epidemics. 2018;22:43-49.

86. Ameri K, Cooper KD. A Network-Based Compartmental Model For The Spread Of Whooping Cough In Nebraska. JAMIA Summits on Translational Science Proceedings. 2019;2019:388.

87. Mahdizadeh Gharakhanlou N, Mesgari MS, Hooshangi N. Developing an agent-based model for simulating the dynamic spread of Plasmodium vivax malaria: A case study of Sarbaz, Iran. Ecological informatics. 2019;54:101006.

88. Montalan JR, Estuar MRJ, Teknomo K, Gardon RW. Measles Metapopulation Modeling using Ideal Flow of Transportation Networks. Paper presented at: Proceedings of the 2nd International Conference on Software Engineering and Information Management2019.

89. Naserpor A, Niakan Kalhori SR, Ghazisaeedi M, Azizi R, Hosseini Ravandi M, Sharafie S. Modification of the Conventional Influenza Epidemic Models Using Environmental Parameters in Iran. Healthc Inform Res. 2019;25(1):27-32.

90. Systrom K, Vladeck T, Krieger M. Rt COVID-19. In: Rt.Live, 2020.

91. Gaskins N. CU Boulder: Increase In COVID-19 Positive Tests Expected. In: Yahoo! News, 2020.

92. Maccabe T. One percent of Purdue students test positive for COVID-19. In: WRTV Indianapolis, 2020 .

93. Mansell W, Lynn S. Significant number of Navy midshipmen test positive on return to school. In: Yahoo! News2020.

94. Rahmandad H, Lim T, Sterman J. Estimating COVID-19 Under-Reporting Across 86 Nations: Implications for Projections and Control. SSRN. 2020.

95. COVID-19 Coronavirus Incubation. In: Worldometer, 2020.

96. Interim Clinical Guidance for Management of Patients with Confirmed Coronavirus Disease (COVID-19). In: $C D C, 2020$.

97. Maragakis L. Coronavirus Diagnosis: What Should I Expect? John Hopkins Medicine. 2020. https://www.hopkinsmedicine.org/health/conditions-and-diseases/coronavirus/diagnosed-with-covid19-what-to-expect. Accessed July 7. 
medRxiv preprint doi: https://doi.org/10.1101/2020.08.29.20184366; this version posted September 13, 2020. The copyright holder for this preprint (which was not certified by peer review) is the author/funder, who has granted medRxiv a license to display the preprint in perpetuity. All rights reserved. No reuse allowed without permission.

98. Sakurai A, Sasaki T, Kato S, et al. Natural History of Asymptomatic SARS-CoV-2 Infection. The New England Journal of Medicine. 2020:1-2.

99. Report of the WHO-China Joint Mission on Coronavirus Disease 2019 (COVID-19). World Health Organization;2020.

100. Mortality Analyses. In: John Hopkins Medicine Coronavirus Resource Center, 2020.

101. Perez-Saez F, Lauer S, Kaiser L, et al. Serology-informed estimates of SARS-COV-2 infection fatality risk in Geneva, Switzerland. In: OSFPREPRINTS, 2020.

102. Wiersinga WJ RA, Cheng AC, Peacock SJ, Prescott HC. Pathophysiology, Transmission, Diagnosis, and Treatment of Coronavirus Disease 2019 (COVID-19): A Review. JAMA. 2020.

103. University of Washington. Novel coronavirus \& COVID-19: facts and resources. 2020; https://www.washington.edu/coronavirus/?utm_source=uwhp\&utm_medium=tiles\&utm_campaign= covid-safe-start.

104. Purdue University. Chronology of Purdue's Response to COVID-19. 2020; https://protect.purdue.edu/timeline/.

105. Richards M, Janes J. Resiliency planning for autumn quarter. In: University of Washington, 2020.

106. Rice University. Return to Rice. 2020; https://coronavirus.rice.edu/.

107. University S. COVID-19 Health Alerts. 2020; https://healthalerts.stanford.edu/covid-19/.

108. Ohio State University. Safe and Healthy Buckeyes. 2020; https://safeandhealthy.osu.edu/.

109. Harter K, Raudins S. President Drake says on-campus transition could begin in coming weeks. In: The Lantern, 2020.

110. Aoun J. University Messages: Our path forward. In: News@ Northeastern, 2020.

111. California State University. Latest Information About Coronavirus 2019 (COVID-19). 2020; https://www.csub.edu/covid-19.

112. Smith A, Burke M, Gordon L. Quick Guide: California colleges and universities respond to the coronavirus. In: EdSource, 2020.

113. Conneticut State University. Eastern Fall Reopening. 2020; https://www.easternct.edu/reopening/index.html.

114. Hladky G. State college and university campuses to reopen for start of fall semester. In: CT Mirror, 2020.

115. Box, GEP, Draper NR (1987). Empirical Model-Building and Response Surfaces. Wiley. New York; 1987.

116. Hurd HS, Kaneene JB. The Application of Simulation Models And Systems Analysis In Epidemiology: A Review. Preventive Veterinary Medicine. 1993;15(2-3):81-99.

117. Murdoch WJ, Singh C, Kumbier K, Abbasi-Asl R, Yu B. Definitions, methods, and applications in interpretable machine learning. Proc Natl Acad Sci U S A. 2019;116(44):22071-22080.

118. Coronavirus (Covid-19) Data in the United States. In: Github.

119. Population Estimates. In: United States Census Bureau. 